vist forståelse for tvetydigheden i Kierkegaards forfatterskab og for det komplementære i forholdet mellem Kierkegaard og Grundtvig er Hinrich Buss (bind I). Harbsmeier trækker Kierkegaard frem som et spøgelse, der sætter Grundtvig i relief, men lader modsætningerne mellem dem stå åbne. Forsøg på at vurdere de to forfattere uhildet og fordomsfrit $i$ lys af hinanden afvises kategorisk som »harmonisieren« (s. 245). Tyskerne må altså selv foretage en sådan vurdering bagom Harbsmeiers og Løgstrups personlige Kierkegaard-fordomme; det, som skulle have været en kontrovers, er blevet til et Grundtvig-portræt på baggrund af en fortegnet Kierkegaard-skitse.

"Kontroverse um Kierkegaard und Grundtvig « har tegnet en dyster karikatur af Kierkegaard og har på den måde uden tvivl opnået reklame for Grundtvig som et manende alternativ til Kierkegaard. Det er synd - Grundtvig skal nok gøre sig gældende uden for Danmark uden en sådan form for reklame.

Hellmut Toftdahl

\title{
Grundtvig til undervisningsbrug
}

N. F. S. Grundtvig: Tre Danne-Virke-artikler (Tekster til undervisningsbrug, 5). Akademisk Boghandel. Århus 1972. 47 sider. Tilsendt af cand. art. Aage Jørgensen. 7 kroner.

Grundtvigs tidsskriftartikler hører til den interessanteste del af hans forfatterskab, men er kun i ringe omfang optrykt i Grundtvig-udgaverne. Dette gælder i særdeleshed hans artikler fra tidsskriftet Danne-Virke I-IV (1816-1819). Det er derfor på den ene side glædeligt, at det nu er muligt at købe tre af hans artikler herfra særskilt, men på den anden side beklageligt, at det foreliggende fotografiske optryk kun omfatter artikler, der allerede tidligere er optrykt. Forlægget er Værker i Udvalg, bind II, 1941. Der savnes i høj grad en kommenteret udgave af alle Danne-Virke-artiklerne, der udgør grundlaget for den tankeverden, Grundtvig byggede op og siden hentede stof fra til sine banebrydende arbejder. - Dette lille udvalg omfatter programartiklen Om dansk Poesi, Sprog og Historie (1816), artiklen Om Ordsprog (1817) samt Grundtvigs indlæg i striden $\mathrm{Om}$ Baggesen og Oehlenschläger fra 1819. Det konstateres med tilfredshed, at det nu ikke blot er de bedst kendte salmer og digte af Grundtvig, der anvendes til undervisningsbrug, men at man også har opdaget forfatteren og kritikeren af samme navn.

\section{Studieserien (udgivet af Dansklarerforeningen)}

Grundtvig og det folkelige ved Marianne Juhl Christiansen og Lise Ettrup.

Gyldendal 1972.

Organismetanken - en hovedlinje i det 19. århundredes tænkning og digtning ved Aage Henriksen med forslag til arbejdsopgaver ved Peter Olivarius. 1973. Tvarsnit 1870 - en samling tekster med opgaveforslag ved Peter Søby

Kristensen. 1973.

Af i alt 14 hæfter til brug for gymnasieundervisningen, spændende fra Skillingsviser til Fantomet, finder man Grundtvigs billede på forsiden af foreløbig 3 et glædeligt vidnesbyrd om den gamles livskraft under den omvæltning, dansk- 
undervisningen nu gennemgår. Allerede i 1972 kom et lille udvalg af tekster fra Grundtvigs folkelige skrifter og digte, efterfulgt af to Ingemann-tekster, to tekster af hans disciple Christen Kold og Chr. Flor og endelig tre af grundtvigianismens kritikere Jakob Knudsen, Henrik Pontoppidan og Andersen Nexø. Der skulde være stof nok til en saglig debat. I et kort forord forsøges følgende definition af begrebet »det folkelige«: »det folkelige er det særegent danske, således som det viser sig i den ikke-dannede del af befolkningen, og som vi kan se det udtrykt $\mathrm{i}$ det danske folks historie og det danske sprog. (For en tysker f.eks. naturligvis det særegent tyske etc.)« - Hvilket er vanskeligt at benægte. Det stemmer med Grundtvig og støttes af de følgende tekster.

I forordet henvises der til hæftet »Organismetanken«, Aage Henriksens udmærkede ny benævnelse på, hvad vi hidtil har kaldt romantik. Og hvad det folkelige angår, kan det ikke nægtes, at Grundtvig var »barn af sin tid«, som man siger, og for så vidt romantiker: folket var ligesom mennesket en levende organisme i udvikling og havde, ligesom det enkelte menneske, en historie. At blive sig denne bevidst var forudsætningen for at kende sig selv og fortsætte sin udvikling. - Men således som organismetanken er belyst i Aage Henriksens hæfte, har den alligevel mere forbindelse med alt det lærde akademikervæsen, som Grundtvigs tanker vendte sig imod, end med Grundtvigs egen tankeverden. Tankeretningen føres nemlig tilbage til Spinoza, Paracelsus og Jakob Böhme og - gennem Goethe, Herder og Schelling - frem til Hegel, Marx og Freud. Af danske repræsentanter for denne tankeretning citeres først og fremmest Henrich Steffens, Paul Diderichsen og - Grundtvig. Eller rettere udelukkende disse tre. For vel er Sibbern og H. C. Ørsted nævnt og Diderichsen citeret for sit svar på Martin A. Hansens Leviathan, ligesom Grundtvig-citatet er kommenteret med et citat af Sophus Claussen: at »Fornuften ikke trænger ned i de Brønde, hvorfra Overbevisningen stiger op « - et meget heldigt (og nødvendigt) greb; men hvorfor er det ikke i stedet Ørsted- og Sibbern-tekster, der er citeret? - Så havde Grundtvig ligesom Martin A. Hansen kunnet spille den rolle, han har, nemlig som modspiller til hele denne tankeretning (bortset fra den nævnte tilslutning til tanken om folket som en organisme).

Den Grundtvig-tekst, Aage Henriksen har trykt, er et afsnit af den fortolkning af Johannes Aabenbaring, Grundtvig i oktober 1810 nedskrev, men aldrig udgav. Torben Brostrøm har oven $\mathrm{i}$ købet $\mathrm{i}$ en anmeldelse kaldt dette bogens "kup«. Men hvis man på det grundlag indrangerer Grundtvig på linie med Hegel, Marx og Freud, så glemmer man, at Grundtvig i december 1810 netop opgav disse højtflyvende tanker for at blive kapellan i Udby, hvilket ikke blot ændrede hans syn på sig selv, men også hans syn på historien. Hvorom henvises til Ehnevid og Ejvind Larsen i dette bind af Grundtvig-Studier samt til min egen bog Den sælsomme Forvandling i N. F. S. Grundtvigs Liv (1956 s. 170 ff).

Grundtvig selv vil man - foruden i de tre Danne-Virke-artikler - med fornøjelse og tilfredshed gense i Peter Søby Kristensens »Tværsnit« af tiden omkring 1870, hvor bogens »kup « er de utvetydige strofer af Budstikke i Høinorden og de meget levende taler fra Marielyst Højskole. Ren, folkelig talerprosa. Men ikke uden underfundighed.

William Michelsen 